SOWHO, P. O. ABAUKAKA, T. O. OBA, U.O.

Federal College of Education, Okene, Nigeria

\begin{abstract}
Unemployment is a condition whereby the able-bodied men and women who are qualified and ready to work do not have commensurate work to do. In Nigeria it has developed to a crises situation as the unemployment now affect both the graduates and non-graduates alike which is principally blamed on mismatch between the skills acquired in institutions of learning and the country labour market needs. This calls for question on the type of education system and the constituents of human capital formation in Nigeria. The paper therefore concluded that the rate of unemployment in Nigeria will continue to increase manifest in multidimensional problem to the economy and the entire social fabrics of the national life if the system of education fails to evolve talents and skills that will use materials resources to develop technology which will be compliant with human potentials. Based on this, the researchers recommended among others that the school curriculum should be review in line with societal demand pattern, education system that will focus on developing indigenous technology and avoid waste of manpower.
\end{abstract}

\title{
Introduction
}

Unemployment in Nigeria has developed to a crisis situation whereby graduates of over a decade still roam the streets of major cities and even local communities without meaningful work to do. Crises on the ground that graduate have become so vulnerable in Nigeria where they are exposed to manipulation of all kinds such as extortion in the disguise of possible job availability, susceptibility to human traffickers and all manners of inhuman treatment being melted to desperate job seekers. Unemployment according to Abaukaka (2014) is used to describe a phenomenon whereby those who are qualified to work do not have meaningful work to do.

Human capital development is the most potent tool for achieving a productive economy that can absorb the growing population. Human capital development in Okwoli (2014) has to do with empowering of people by fostering the contributory capacities that they can bring to the improvement of their quality of life and that of their families, communities, enterprises and societies. Human capital refers to the abilities and skills of human resources (Kanayo, 2013). It is referred to the knowledge, skills, competences and attributes embodied in individuals that facilitate the creation of personal, social and economic well being (Marimuthu, Arokiasamy \& Ismail, 2009). The innate abilities in human factor need development on constant basis to acquire skills which can match with the need of the labour market. According to Dobson and Boodoo (2013) human capital is more than size of a country's population of labour force age which is assumed generally but it is about augmenting labour force skills. Endres and Herper (2013) opined that the development proceeds, enterprise level knowledge and learning are critical for qualitative economic change. This is necessary because the society is a dynamic one and human factor has to be built to match up with the world of dynamism. This view can be likened to Aluko and Aluko (2012) that see human capital as all persons who work now and likely to be productively employed sooner or later. They maintained that it is a continuous process from childhood to old age and a must for any society or enterprise that wishes to survive under the complex challenges of a dynamic world. 
The problem of Nigeria's unemployment crises is not just lack of education or skills but it may be described as a mixture of lack of opportunities and skills mismatch. Njoku and Ihugbe (2011) viewed that unemployment among those without primary school education in 1974 was $76.8 \%, 80.6 \%$ t in 1976 but the situation has been compounded by increasing unemployment of professionals such as engineers, accountants and other professional alike in Nigeria. The human capital development is a people centered strategy of development and implies the active participation of people in the development process and the consequences need to construct institutions that permit and encourage participation (Aluko \& Aluko, 2012).

The level of participation of people in terms of educational policy formations calls for a re-examination due to the paradoxical situation where there is a co-existence of increasing number of graduates and unemployment in Nigeria. The issue is a problem of absorption capacity problem which is not far from the foreign sectors dominated economy as well as oil dependent economy. Okwoli (2014) suggests the need for education planners in Nigeria to ask a number of questions such as to find out whether education sector in Nigeria produces unemployed graduates due to the lack of appropriate signaling from the labour force, what kinds of skills are in shortage and what reforms are needed in our educational system.

\section{Human Capital Development}

Human capital development is the continuous improvement on ones education and health status in order to remain vibrant and productive in a sustainable manner. It is a way to fulfill capabilities which implies empowerment of people as well as enabling them to participate actively in their own development (Aluko \& Aluko, 2012). It is achieved according to Forester, Ustinova, Kosyakowa, Ronzhina and Suraeva (2016) through investments in education, health, knowledge, entrepreneurial skills, information provision, safety and economic freedom of population; and investments in science, art and culture. Dobson and Boodoo (2013) opined that education is key and the skills which is relevant to the people must be provided as the labour force expansion becomes an asset if workers have incentive to be productive and if otherwise, a potential burden if they do not. Human capital development has a health dimension as good economic performance or productivity is viewed as positive function of good health condition of the people or a given society. According to Ishola and Alani (2012), sound health enhances worker's productivity through the spillover effects on their physical and mental abilities.

\section{Unemployment}

When the qualified able bodied men and women who are ready to be employed do not have suitable job which is consistent with their skills, the situation is referred to as unemployment. World Bank in Njoku and Ihugba (2011) define unemployment as numbers of the economically inactive population who are without work but are available for and seeking for work as well as people who have lost their jobs involuntarily or voluntarily. Unemployment in Nigeria seems to have defiled the existing forms of unemployment on the ground it is endemic and seems not policy responsive. Okwoli (2014) associates unemployment in Nigeria to skills mismatch and not just lack of skill. He blamed it on the country's lack of capacity to take 
advantage of opportunities in the global market such as through technology adoption and development of new export industries.

\section{Human Capital Development and Way Out of Unemployment Crises}

According to Okwoli (2014), human resource development which has to do with empowerment of the people to improve on the quality of their lives is seen to facilitate the development of national human capacities to achieve sustainable development and at the same time enhance well-being of individuals. The idea behind enhancement of human capacities is to ensure they become relevant in every facet of economic and social lives of the society. That is, the human factor becomes employable and at the same time capable of creating wealth.

Investment in people indirectly formulates to investing in other productive factors. According to Forrester et al (2016), without people, it is impossible to implement further new technologies in the scale of different forms, industries and the country as a whole. They added that education of people develops the capacity that allows the community to move forward, to progress, to update and change, including the economic sphere. The core issue here is ability of Nigeria's educational system to provide skills that can combine both human and material resources to bring about goods and services for self-sufficiency in the economy. The realization of this, where the economy can provide absorptive capacity to bring about employment of abundant human resources as well as adequate utilization of available physical and material resources.

Aluko and Aluko (2012), viewed that human capital development is people centered strategy of development which is basically to empower the people to enable them identify their own capabilities and to implement programmes and projects that are of benefit to them. According to Endres and Herper (2013) human capital development will call forth resources and abilities that are hidden, scattered or badly utilized.

The government has over the years taken a leading role in the economic activities of Nigeria and because of inherent institutional and financial bottlenecks. Private sector initiatives can hardly augment the needed investment graps in Nigeria. This scenario is seen to exerbate the unemployment crises in Nigeria. There is now skill mismatch in the economy due partly few productive organizations in Nigeria import technologies and even expertise especially the multinationals. This is why Okwoli (2014) reasoned that the challenging issue before less developed countries including Nigeria is how to organize their educational system so that expansion of education is matched by creation of opportunities productively utilizing a better educated workforce. Similarly, Adebayo (2013) observed that average Nigerian graduate is unemployable because of lack of necessary skills needed by employers of labour for a formal sector due to lack of entrepreneurial contents of most Nigerian higher institutions required to make graduates employers of labour instead of job seekers.

Nigeria has perpetual problems of educational deficit in terms of enrolment, educational facilities, and lack of synergy with the industry and delayed graduation period. Baah-Boateng (2013) sees African countries to be generally underperforming in terms of educational infrastructure whereby available institutions are ill-equipped in terms of facilities and personnel to carrying out effective training. He added that in 
contrast, South East Asian countries of Malaysia, South Korean and Singapore focused their priorities and commitments to ensure that their educational sector boost the supply and quality of human capital base of the countries.

The official figures of rate of unemployment in Nigeria may not be so realistic because accurate data collection which is peculiar nature of developing countries including Nigeria but there are several manifestations that suggest that Nigeria has really entrapped in unemployment crises. This ranges from brain drain syndrome, volume of application for few jobs vacancy slots, social problems and growing trend of insecurity. According to SIHMA (2014), the inability of labour market to absorb the surplus labour and low levels of income leave no other option for the youth but to emigrate. The emigration has serious implication for skills deficit as the very best brains from Nigeria in most cases find her way out of the country.

Similarly, the Federal Ministry of Labour and Productivity (2013), reported that most emigrants who left Nigeria predominantly the young did so to seek for employment and improve their standard of living of whom many have died and some serving in various prisons in their desperate fight for survival. Nigerian youths work under poor condition and are mostly underemployed in terms of wage earned as many of those particularly working with private sectors even with some states government in Nigeria are paid below commensurate wage. This is consistent with the ILO report of 2012 where Nigeria was only rated higher than countries (Burundi, Liberia, Guinean, Madagascar, Mozambique and Nigeria) among 54 countries sampled for employed youths who are working poor at $\$ 2$ per day.

All these harsh economic condition lend credence to youth restiveness and serial criminal activities across the breath and length of the country. According to Adesina (2013), the unemployment can be linked with security challenges in Nigeria ranging from armed robbery, kidnapping, insurgency activities of boko haram and other violent activities which are likely to affect legitimate social and economic activities in the country.

\section{Conclusion}

The rate of unemployment in Nigeria will continue to remain unabated and manifest in multidimensional problem to the economy and the entire social fabrics of the national life if the system of education fail to evolve talents and skills that will use materials resources to develop technology which will be compliant with human potentials.

\section{Recommendations}

To stem the issue of unemployment crises in Nigeria, the human capital development should be directed towards the following considerations:

1. The curriculum of education in Nigeria should change in line with the realities of the economy in terms of societal demand, technology and fashion in tandem with the trend in the global market.

2. The indigenous technology should be the focus of the Nigeria's educational system. The technology adoption and development should be the very type that will not displace those in the labour market. 
3. There should be continuous training and retraining of the employees at both public and private sector levels. This will make the labour force to be innovative and become problem solvers.

4. Substantial allocations should be devoted to educational sector to meet up with the infrastructural gaps or deficit.

5. The graduates should be empowered in line with their chosen profession in order to become employable and even be able to start self help careers.

\section{References}

Abaukaka, T. O. (2014). Foreign direct investments and employment generation in Nigeria. Being a paper preserved at $3^{\text {rd }}$ interacting congress on Business and economic research at FCT, Education Resource Centre Wuse Abuja, July 7-9.

Acemoglu, D. (2017). Lecture notes for Economics.homes.chass.utoronto.cal2801.acemoglu-notes.pdf. Retrieved on July 31, 2017.

Adebayo, A. A. (2013). Youth's unemployment and crime in Nigeria: A nexus and implications for national development. International Journal of Sociology and Anthropology, 5(8): 350-357.

Adesina, O. S. (2013). Unemployment and security challenges in Nigeria. International Journal of Humanities and Social Science, 3(7): 147-155.

Baah-Bonteng, W. B. (2013). Human Capital Development: The Case of Education as a Vehicle for Africa's economic Transformation. Legion Journal of International Affairs and Diplomacy, 7(1): 31-55.

Becker, G. (1964). Human Capital. A Theoretical and Empirical Analysis with Special Reference to Education. Chicago: The University of Chicago Press.

Bohves, S. \& Gintis, H. (1975). The problem with human capital theory. A maximum critique. The American Economic Review, 65 (2): 74-82.

Dobson, W. \& Boodoo, W. (2013). Human Capital Formation and Growth: Microeconomic dimensions. Routledge: London and New York.

Endres, A. M. and Herper, D. A. (2013). Capital formation and internationalist dynamics in development economics. The Evolution and Economic Systems, 24 (2): 335 - 355. Econ.as.nyu.edu/---/nyu-colloquium. Retrieved on November 3, 2016.

Federal Ministry of Labour and Productivity (2013). Labour Migration Policy for Nigeria. Labour-Migration-policy-ff-1.pdf. Retrieved on July 21, 2017.

Habbison, F. H. (1973). Human Resources Development Planning in Modernizing Economies. International Labour Review, 453-458

I.M.F (2017). World economic outlook Nigeria. Opendataforafrica.org/. Retrieved on July 31, 2017.

Litwin, B.S. (2015). Determining the effect of the minimum wage on income inequality. The Cupola, spring (2015), 1-22. 
Machlup, F. (1982). Issues in the theory of human capital: Education as investment, Pakistan Development Review. 19(1): 1-16.

Njoku, A. \& Ihugba, A.O. (2011). Unemployment and Nigeria economic growth (1985-2009). International Association for Teaching and Learning, 1 (1): 1-11.

Okwoli, A. A. (2014). Nigerian educational system: Meeting the human capital needs. Being a paper presented at the second induction and national workshop of the Chattered Institute of Human Capital Development in Nigeria at the conference hall of the office of the Secretary to the Government of the Federation Abuja on May 23, 2014.

Scalarbrini Institute for Human Mobility in Africa (SIHMA) (2014). Migration profile: Nigeria migration_profile_nigeria.pdf. Retrieved on 21/07/2017.

Teixera, P. (2017). Jacob Mincer and the Centrality of Human Capital for Contemporary Labour economics. 5-Teixera.pdf (Pedrotxfed.u.pt.) retrieved on $23^{\text {rd }}$ July, 2017. 